УДК 903.27

https://doi.org/10.24852/2587-6112.2020.5.39.49

\title{
НАСКАЛЬНЫЕ ИЗОБРАЖЕНИЯ КАРАТАША
}

\author{
(C) 2020г. О.А. Кащей
}

В статье анализируется новое скопление наскальных изображений в районе трех высших точек хребта Каржантау. Скопление было найдено и обследовано автором в 2017-2018 гг. Фотодокументирование петроглифов и дальнейшая цифровая пост-обработка материалов дали возможность сформировать качественную источниковую базу полевого исследования памятника и в дальнейшем провести детальный анализ сюжетного ряда Караташа, стилистических и иконографических особенностей 20 наложений изображений, зафиксированных на камне, выделив при этом две разновременные группы петроглифов, а также определить специфику организации «картинной» галереи памятника в горном пространстве основных скоплений Каракиясая. Большой интерес представляет исследование патинизации палимпсестов, позволяющее наметить ранее не известные аспекты технологии создания наскальных изображений и обозначить два возможных объяснения факта более интенсивного темного пустынного загара на верхних слоях палимсестов и более светлого - на нижних. В работе также приводятся результаты анализа техники исполнения образов наскальной галереи, информация о степени сохранности изображений, дается предварительная датировка петроглифов и прочтение фрагмента надписи, выполненной на Караташе арабской графикой, затрагиваются вопросы об особом предназначении уникального камня, как высшей точки горного «храма».

Ключевые слова: археология, наскальное искусство, петроглифы Каракиясая, изобразительные образы, стилистика, палимпсесты, патинизация изображений.

\section{ROCK IMAGES OF KARATASH²}

\section{O.A. Kashchey}

The deals with analysis of new cluster of rock carvings in the region of the three highest points of the Karzhantau ridge. The cluster was discovered and surveyed by the author in 2017-2018. Photo-documentation of petroglyphs and further digital post-processing of materials made it possible to form a high-quality source base for field studies of the monument and to conduct a further detailed analysis of the plot of Karatash, stylistic and iconographic features of 20 overlays of images carved on stone, highlighting two different groups of petroglyphs, as well as to determine the specifics of the organization of the 'picture' gallery of the monument in the mountainous space of the main clusters of Karakiyasay. Of great interest is the study of the patinization of palimsests, which allows to outline previously unknown aspects of the technology of creating rock carvings and to indicate two possible explanations for the fact of a more intense dark desert varnish on the upper layers of palimsests and a lighter varnish on the lower ones. The paper also features the results of an analysis of the technique of creating images of the rock gallery, information on the degree of preservation of the images are also provided, and preliminary dating of the petroglyphs and the wording of a fragment of an inscription made in Karatash using Arabic graphics, addressing the issues of the special purpose of the unique stone as the highest point of a mountain 'temple'.

Keywords: archaeology, rock art, petroglyphs of Karakiyasay, figurative images, stylistics, palimpsests, patinization of images.

Караташ (в переводе с узбекского языка топоним означает «черный камень») - это крупная патинизированная каменная глыба угловатой формы (длина которой составляет 11,75 м, высота-3,85 м), расположенная в предвершинной части одной из трех высших точек хребта Каржантау (со стороны Узбекистана), на высоте около 2550 м н. у. м. Уникальный камень с петроглифами находится примерно на одинаковом удалении от основных скопле-

ний наскальной галереи Каракиясая: на расстоянии 2 км от Каракиясая I и Каракиясая II и на расстоянии 3 км от наскальных изображений в районе урочища Куль и петроглифов Аулиесая (рис 1). Караташ хорошо виден не только со всех скоплений Каракиясая, но и с горных отрогов Чаткальского хребта, расположенных на противоположном берегу реки Чирчик. Подняться на Караташ можно двумя основными маршрутами: от урочища Куль

\footnotetext{
1 Исследование выполнено при финансовой поддержке РФФИ в рамках научного проекта № 20-39-90009.

2 Acknowledgments: The reported study was funded by RFBR, project number 20-39-90009.
} 
через Каракиясай I (набор высоты по данному пути составляет около 600 м, длина - 3 км) и с Каракиясая II (необходимо подняться более чем на 700 м, преодолев 2 км по крутому скалистому гребню).

В окрестностях Караташа были зафиксированы небольшие скопления камней с одиночными образами горных козлов, выровненная площадка для стоянки и действующий родник.

В 2017-2018 гг. на 17 изобразительных плоскостях Караташа было выявлено 175 отдельных наскальных изображений (Кащей, 2019а, с. 129). Документирование петроглифов проводилось в осеннее время года с помощью фотоаппарата Canon EOS 1Ds Mark II и объективов EF17-40 f4 и EF100 f2,8 macro, с последующей камеральной цифровой обработкой и прорисовкой всех изображений на базе полученных фотоматериалов (были использованы программные комплексы CaptureOne, Adobe Photoshop и DStretch). В ходе процесса постобработки и прорисовки петроглифов «проявились» пласты наскальных изображений, которые «in situ» не фиксировались. В общей сложности на Караташе было определено 211 отдельных изображений, 28 из которых идентифицировать не удалось из-за плохой сохранности петроглифов.

С учетом естественных границ и угла наклона плоскостей камня на поверхности Караташа выделяются 17 отдельных панелей, схему расположения которых можно условно представить в следующем виде:

1. Панель 1-8 - патинизированная лицевая часть камня (рис. 2).

2. Панель 9 - непатинизированная обратная сторона камня.

3. Панель 10-17 - патинизированная верхняя часть камня.

Анализ сюжетного ряда петроглифов Караташа, проведенный по цифровым фотографиям и прорисовкам, позволил внести коррективы в ранее полученные нами данные и составить более полную картину соотношения изобразительных образов на его 17 каменных «полотнах» (табл. 1). Как свиде-

Изобразительные образы петроглифов Караташа

Таблийа 1

Graphic images of the Karatash petroglyphs

\begin{tabular}{|c|c|c|c|c|c|c|c|c|c|c|}
\hline 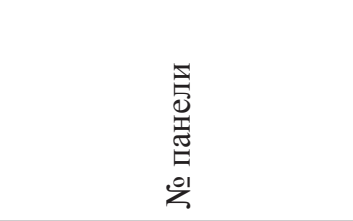 & 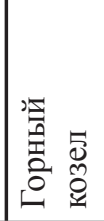 & $\begin{array}{l}1 \\
0 \\
0 \\
0 \\
0 \\
0 \\
0 \\
0\end{array}$ & 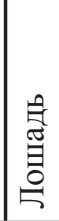 & 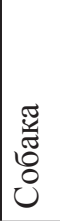 & 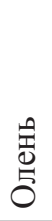 & 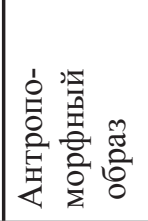 & $\begin{array}{l}\text { 节 } \\
\text { m }\end{array}$ & 茕 & 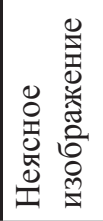 & $\begin{array}{l}\stackrel{0}{0} \\
\ddot{n} \\
\ddot{n}\end{array}$ \\
\hline 1 панель & 9 & 3 & 2 & - & - & 6 & - & - & 3 & 23 \\
\hline 2 панель & 15 & 1 & 1 & 1 & - & 3 & 1 & - & - & 22 \\
\hline 3 панель & 2 & - & - & - & - & - & - & - & - & 2 \\
\hline 4 панель & 30 & 1 & 5 & 2 & - & 15 & - & - & 12 & 65 \\
\hline 5 панель & 10 & - & 2 & 1 & 1 & 5 & - & - & 2 & 21 \\
\hline 6 панель & 8 & - & 2 & - & - & 2 & - & - & - & 12 \\
\hline 7 панель & - & - & 1 & - & - & - & - & - & - & 1 \\
\hline 8 панель (с надписью) & - & - & - & & - & - & - & - & - & - \\
\hline 9 панель & 1 & - & - & & - & - & - & - & - & 1 \\
\hline 10 панель & 1 & - & - & & - & - & - & - & - & 1 \\
\hline 11 панель & 4 & - & - & & - & - & - & - & 1 & 5 \\
\hline 12 панель & 3 & - & - & & - & - & - & - & - & 3 \\
\hline 13 панель & 3 & - & - & 1 & - & - & - & - & 1 & 5 \\
\hline 14 панель & 2 & - & - & 1 & - & - & - & - & 3 & 6 \\
\hline 15 панель & 22 & - & 1 & 2 & - & 2 & 2 & 1 & 4 & 34 \\
\hline 16 панель & - & - & 1 & - & - & - & - & - & - & 1 \\
\hline 17 панель & 4 & - & 1 & 2 & - & - & - & - & 2 & 9 \\
\hline Итого: & 114 & 5 & 16 & 10 & 1 & 33 & 3 & 1 & 28 & 211 \\
\hline
\end{tabular}


тельствуют табличные данные, большая часть петроглифов сконцентрирована на лицевой части камня - 145 фигур (68,7\%), остальные изображения находятся на верхнем ярусе Караташа - 65 изображений $(30,8 \%)$ и одно изображение горного козла $(0,5 \%)$ на задней плоскости камня.

На торцевых панно передней части «картинной» галереи обращает на себя внимание особое оформление центральной плоскости (4 панель), на которой представлено 65 петроглифов (30\% от всех изображений) (рис. $3)$ и концентрация изображений на панели № 15 , находящейся в верхней «галерее» уникального камня, где представлено 34 петроглифа (16\% от всех изображений) (рис. 4).

При этом следует отметить «популярность» на передних торцевых изобразительных плоскостях Караташа фигур верблюдов (100\%), антропоморфных образов (94\%), лошадей $(75 \%)$, горных козлов $(65 \%)$ в сравнении с общим количеством изображений соответствующих образов на других участках камня.

Ведущим зооморфным образом здесь, как и на «полотнах» других скоплений Каракиясая (Кащей, 2020, с. 324), выступает образ горного козла (62\%), который, судя по иконографическим особенностям исполнения фигур горных животных и имеющихся сведениях о фаунистическом комплексе региона, можно соотносить с сибирским козлом (Capra sibirica Pallas) (Ишунин, Тетюхин, 1989, с. 67-68). Намного реже встречаются изображения лошади $-9 \%$, собаки - 5\%, верблюда - 3\% и оленя - $0,5 \%$. Обращенные в правую сторону фигуры животных численно преобладают над обращенными влево.

Антропоморфные образы составляют 18\% от всех идентифицированных фигур Караташа. Своеобразным «ядром» центрального каменного «холста», сразу притягивающим к себе взгляд, выступают парные антропоморфные фигуры (рис. 3), оформленные в профильной проекции, которые также неоднократно откликаются и на соседних панно главной галереи Караташа (рис. 2; 3; 5) и полностью отсутствуют на «полотнах» верхней части галереи. Анализ планиграфии панели № 4 позволяет предположить, что парные образы, вероятно, были созданы одними из первых, т. к. занимают самую центральную часть каменной «картины».
Антропоморфные существа также выступают связующим компонентом в следующих сюжетных «сценах»:

- антропоморфный образ, держащий на поводу словно упирающегося верблюда (панель 1) (рис. 6: 1);

- антропоморфные фигуры, «поймавшие» за хвост горного козла;

- одиночные и парные образы людей в окружении животных (в большинстве случаев горных козлов), выполненные в фронтальной и фронтально-профильной проекции с поднятыми вверх руками (некоторые из них с палками (?)), с поясным орудием/колчаном (?) и подчеркнутым признаком мужского пола (панели 2, 4, 5, 6, 15) (рис. 3; 4; 7).

При сопоставлении количества сюжетных композиций Караташа с многофигурными «сценами» на других скоплениях (Каракиясай I, Каракиясай II) отмечается большая сдержанность в выражении многоплановых сюжетов и преобладание одиночных образов. Здесь не встречаются «сцены» охоты с участием лучников, мотивы шествия различных видов животных, которые так характерны для других скоплений Каракиясая (Кащей, 20196, с. 44-45).

На памятнике зафиксированы также 3 знака и волнистая линия (рис. 4: 1-2; 7: 3). Особый интерес представляет знак, имеющий определенное сходство с одной из самых распространенных разновидностей бактрийско-маргианских печатей (Рогожинский, 2011, с. 90-91) (рис. 4). Подобное сочетание знака и линии в окружении животных встречается на петроглифах Шалабай (Каратау) (Мургабаев, 2013 , с. 54, рис. 6 ).

На панели № 8 Караташа была зафиксирована часть надписи, представляющая собой обрывки двух строк на арабской графике (продолжение каменного «листа» отсутствует) (рис. 2; 8). Если, к примеру, на Каракиясае I некоторые надписи нанесены поверх древних образов, то в данном случае автору удалось гармонично «вписать» текст в пространство каменной галереи с рисунками. По мнению ведущего научного сотрудника Российского научно-исследовательского института культурного и природного наследия им. Д.С. Лихачева (г. Москва) к.и.н. И.В. Волкова, предположительные прочтения надписи могут быть следующие:

1 вариант: ный)...
吕 - ...и выделенный (отобран- 


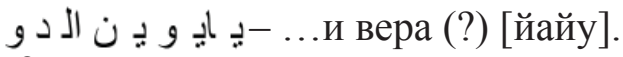

2 вариант:

و فروز

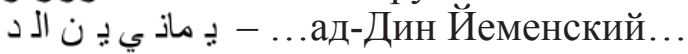

Но ввиду того, что возможно продолжение строк, не исключены и другие варианты прочтения надписи.

Всего на панелях Караташа было выявлено более 20 палимпсестов (рис. 6). Анализ структуры последовательности наложений изображений фигур животных указывает на возможность выделения на памятнике двух разновременных групп наскальных изображений:

1. Наиболее древние пласты фигур животных выполнены с 4 нижними конечностями и 2 рогами в силуэтной, контурной и линейной манере исполнения (рис. 6: 1-4).

2. Для поздних пластов наскальных изображений характерны силуэтные и линейные фигуры горных козлов, которые представлены в двух вариантах:

- с 2 нижними конечностями и 2 рогами (рис. 6: 3);

- с 2 нижними конечностями и 1 рогом (рис. 6: 4).

Степень выветренности наскальных изображений Караташа достаточно высока, особенно сложно фиксируются следы выбивки рисунков на горизонтальных панелях, расположенных в верхней части «картинной» галереи. Как показал анализ стратиграфии петроглифов на лицевых панно, техника выполнения более древних пластов наскальных изображений имеет довольно крупный диаметр точек и частую выбивку - силуэтная линия таких фигур неровная и грубая. Верхние слои фигур животных проработаны более тщательно, нередко со сглаженной поверхностью, но при этом также часто с грубыми, «рваными» контурами очертаний фигур. Некоторые петроглифы Караташа миниатюрные, созданы с помощью мелкоточечной выбивки. Встречаются изображения с гравировкой, а также с предварительным наброском контура рисунка с помощью прорезания поверхности камня острым предметом. На Караташе были зафиксированы два гравированных тонкими линями схематичных изображения лошади.

Но, пожалуй, самым уникальным явлением наскальных изображений Караташа следует считать палимпсесты, выполненные на панелях № 2 и № 15 (рис. 4: 1-2; 7: 1-2). Еще в 1977 г. М.К. Кадырбаевым и А.Н. Марьяшевым был детально рассмотрен вопрос о серьезных недостатках метода датировки петроглифов по патине. Авторы пришли к заключению, что данный метод дает убедительные результаты в случае анализа разновременных гравировок, расположенных на одной плоскости или на разных участках, но находящихся по отношению друг к другу в одинаковых условиях (Кадырбаев, Марьяшев, 1977, с. 152-155). Я.А. Шер для сопоставления степени загара на древних рисунках указывал на необходимость выбора плоскостей, строго одинаково ориентированных к солнцу (Шер, 1980, с. 172). Такого же мнения придерживался и M.M. Хужаназаров, который условно выделял 4 степени патинизации петроглифов Каракиясая (Хужаназаров, 1995, с. 56-57). Однако яркой иллюстрацией, противоречащей приведенным выше заключениям (которые не утратили своей актуальности и в современной науке), являются примеры палимпсестов Караташа. Два разновременных слоя с петроглифами, созданные на одних участках (находящихся в равных условиях), имеют в случае более раннего (нижнего) изображения горных козлов (панель № 2) (рис. 4: 1-2) и извилистой линии (панель № 15) (рис. 7: 1-2) светлую патину, а на наложенных поверх них позже фигурах животных - темный цвет пустынного загара.

Приведенное «исключение» из устоявшихся правил ранее на петроглифах бассейна реки Чирчик зафиксировано не было. Возможно, подобное явление может быть объяснено следующими нюансами технологии создания изображений:

1. Фигуры создавались с помощью использования различных инструментов (каменными орудиями были выбиты ранние пласты изображений, а металлическими - фигуры верхнего слоя), поэтому и следы редкого пикетажа в нижележащем слое патинизировались менее интенсивно, чем созданные позже металлическим предметом образы, которые наносились на поверхность камня техникой сплошной выбивки и «загорали» быстрее. Возможно здесь также имел значение сам материал инструмента, вступавший «в реакцию» с микрофлорой скальной поверхности.

2. Поздние изображения горных козлов в процессе/после создания смазывались маслом, жиром или каким-то маслянистым составом, что в свою очередь ускорило процесс патинизации фигур животных. По этнографическим сведениям, которые приводятся Н.И. Веселовским, подобные процедуры смазывания 
маслом высеченных на камнях изображений имели место в прошлом (Протоколы заседаний Восточного отделения Императорского Русского Археологического Общества, 1887 , c. XVI).

На панели № 15 Караташа были выявлены три случая подновления образов горных козлов, и в настоящее время они имеют очень светлый цвет патины (рис. 4).

Стилистические и иконографические особенности исполнения фигур животных, антропоморфных образов, представленных на Караташе и имеющих аналогии не только на петроглифах Каракиясая и наскальных изображениях бассейна реки Чирчик, но и среди широкого круга памятников Южного Казахстана, Узбекистана и Киргизии, позволяют отнести наиболее ранние пласты изображений Караташа к эпохе развитой и поздней бронзы. Наличие фигур горных козлов, выполненных в сакском стиле (рис. 3), а также в тамгообразной манере исполнения образов горных животных, многократно представленной на верхнем «этаже» Караташа (Савинов, 2015 , с. 66), указывают на «традицию» посещения памятника, продолжающуюся как в эпоху раннего железного века, так и в древнетюркское время. Заключительным «аккордом» почитания особенного камня с петроглифами можно считать надпись, выполненную арабской графикой.

Удаленность Караташа, его труднодоступность в сравнении с другими скоплениями Каракиясая, возможно, могла быть связана с особым предназначением этого места, расположенного на крутом неуютном склоне в окружении труднопроходимых скальных поясов. Дуальные антропоморфные образы на центральных панно, преобладание одиночных фигур горных козлов по всему пространству своеобразного каменного «алтаря», а также уникальная надпись указывают на совершенно иную семантическую наполненность пространства каменной «галереи», где полностью отсутствуют яркие и многофигурные «сцены» охоты с участием лучников и большим видовым разнообразием и количеством животных, которыми «пронизаны» основные скопления Каракиясая. Также важно отметить, что петроглифы Караташа являются ярким свидетельством некой необходимости создания изображений в более труднодоступном, сокрытом участке памятника, восхождение к которому предполагает большие энергозатраты.

На каменных полотнах «галереи» Караташа выявлены случаи поглощения лишайниками изображений (рис. 9) и плохая сохранность фигур на верхнем горизонтальном ярусе камня. В настоящее время полевые исследования уникальных петроглифов связаны с определенными трудностями, касающимися не столько сложности преодоления горного рельефа, а сколько с местоположением памятника близ границы двух государств: Казахстана и Узбекистана, поэтому все вопросы, связанные с дальнейшим изучением и сохранением наскального искусства Караташа, пока остаются открытыми.

\section{ЛИТЕРАТУРА}

Ииунин Г.И., Тетюхин Г.Ф. Вероятные пути образования фауны млекопитающих на территории Узбекистана. Ташкент: Фан, 1989. 80 с.

Кадырбаев М.К., Марьяшев А.Н. Наскальные изображения хребта Каратау. Алма-Ата: Изд-во «Наука» КазССР, 1977. 232 с.

Кащей O.A. Неизвестные наскальные изображения Каракиясая // LI Урало-Поволжская археологическая студенческая конференция (УПАСК, 5-8 февраля 2019 года): материалы всероссийской (с международным участием) конфе-ренции студентов, аспирантов и молодых ученых / Ред. Д.Н. Маслюженко, И.К. Новиков. Курган: Изд-во Курганского гос. ун-та, 2019б. С. 43-45.

Кащей O.A. Новое скопление петроглифов в верховьях Аулиесая на хребте Каржантау (по итогам экспедиции 2019 г.) // Актуальная археология 5. Комплексные исследования в археологии. Материалы Международной научной конференции молодых ученых (13-16 апреля 2020 г., Санкт-Петербург) / Отв. ред. К.В. Конончук. СПб.: Изд-во ООО «Невская Типография», 2020. С. 323-327.

Мургабаев С.С. Проблемы хронологии и культурных связей ранних петро-глифов Каратау // Научное обозрение Саяно-Алтая. 2013. № 1. С. 52-65.

Протоколы заседаний Восточного отделения Императорского Русского Археологического Общества // Записки Восточного отделения Императорского Русского Археологического Общества. Т. I. СПб.: Типография Императорской Академии Наук, 1887, С. I-XX. 
Рогожинский A.E. Образы и реалии древнеземледельческой цивилизации Средней Азии в наскальном искусстве эпохи бронзы Южного Казахстана и Семиречья // Наскальное искусство в современном обществе. К 290-летию научного открытия Томской писаницы. Материалы международной научной конференции. (Кемерово, 22-26 августа 2011 г.) Т. 2. Кемерово: Кузбассвузиздат, 2011. С. 87-99.

Савинов Д.Г. Тамгообразные изображения горных козлов, или к определению фарна древнетюркских каганов // Теория и методология архаики. Вып. VIII. / Отв. ред. М.Ф. Альбедиль, Д.Г. Савинов. СПб: Музей антропологии и этнографии им. Петра Великого РАН, 2015. С. 64-74.

Хужаназаров М.M. Наскальные изображения Ходжакента и Каракиясая. Самарканд: Институт археологии АН РУз, 1995. 174 с.

Шер Я.А. Петроглифы Средней и Центральной Азии. М.: Наука, 1980. 325 с.

\section{Информация об авторе:}

Кащей Олеся Анатольевна, Казанский (Приволжский) федеральный университет (г. Казань, Россия); Shukunja@mail.ru

\section{REFERENCES}

Ishunin, G. I., Tetyukhin, G. F. 1989. Verojatnye puti obrazovanija fauny mlekopitajushhih na territorii Uzbekistana (Probable Formation Routes of the Mammalian Fauna in the Territory of Uzbekistan). Tashkent: "Fan" Publ. (in Russian).

Kadyrbaev, M. K., Mar'yashev, A. N. 1977. Naskal'nye izobrazheniia khrebta Karatau (Rock Carvings of the Karatau Mountain Ridge) Alma-Ata: "Nauka" Kazakh SSR Publ. (in Russian).

Kashchey, O. A. 2019. In Maslyuzhenko, D. N., Novikov I. K. (eds.). LI Uralo-Povolzhskaya arkheologicheskaya studencheskaya konferentsiya (UPASK, 5-8 fevralya 2019 goda): materialy vserossiyskoy (s mezhdunarodnym uchastiem) konferentsii studentov, aspirantov i molodykh uchenykh (51 $1^{\text {st }}$ Ural-Volga Archaeological Student Conference (UPASK, February 5-8, 2019): Proceedings of the All-Russian (with International Participation) Conference of Students, Postgraduates and Young Scientists). Kurgan: Kurgan State University Publ., 43-45 (in Russian).

Kashchey, O. A. 2020 In Konochuk, K. V. (ed.) Aktual'naia arkheologiia: kompleksnye issledovaniia v arkheologii (Current Archaeology: Comprehensive Studies in Archaeology) 5. Saint Petersburg: "Nevskaya Tipografi-ya" Publ., 323-327 (in Russian).

Murgabaev, S. S. 2013. In Nauchnoe obozrenie Saiano-Altaia (Scientific Review of Sayano-Altai) 1. $52-65$. (in Russian).

Protokoly zasedaniy Vostochnogo otdeleniia Imperatorskogo Arkheolog-icheskogo obshchestva (Minutes of the Meetings of the Eastern Branch of the Imperial Russian Archaeological Society) 1887. In Zapiski Vostochnogo otdeleniia Imperatorskogo Russkogo arkheologicheskogo obshchestva (Proceedings of the Oriental Branch of the Imperial Russian Archaeological Society) I. Saint-Petersburg: Imperial Academy of Sciences Publ., I-XX (in Russian).

Rogozhinskiy, A. E. 2011. In Naskal'noe iskusstvo v sovremennom obshchestve. K 290-letiyu nauchnogo otkrytiia Tomskoi pisanitsy. Materialy mezhdunarodnoi nauchnoi konferentsii (Kemerovo, 22 - 26 avgusta 2011) (Proceedings of International Research Conference "Rock Art in Modern Society. On 290th annieversary of the discovery of Tomskaya Pisanitsa". Keme-rovo, 22-26.08.2011). 2. Kemerovo: "Kuzbassvuzizdat" Publ., 87-99 (in Russian).

Savinov, D. G. 2015. In Albeldil, M. F., Savinov, D. G. (eds.). Teoriia i metodologiia arkhaiki (Theory and Methodology of Antiquities) 8. Saint Petersburg: Peter the Great Museum of Anthropology and Ethnography (Kunstkamera) of Russian Academy of Sciences, 64-74 (in Russian).

Smirnov, K. F. 1995. Naskal'nye izobrazheniia Khodzhakenta i Karakiiasaia (Rock Carvings of Khojakent and Karakiyasay). Samarkand: Insti-tute of Archaeology of the Uzbekistan Academy of Sciences (in Russian).

Sher, Ya. A. 1980. Petroglify Sredney i Tsentral'noi Azii (Petroglyphs of the Middle and Central Asia). Moscow: "Nauka" Publ. (in Russian).

\section{About the Author:}

Kashchey Olesya A. Kazan (Volga Region) Federal University. Kremlyovskaya str., 18, Kazan, 420008, the Republic of Tatarstan, Russian Federation; Shukunja@mail.ru 


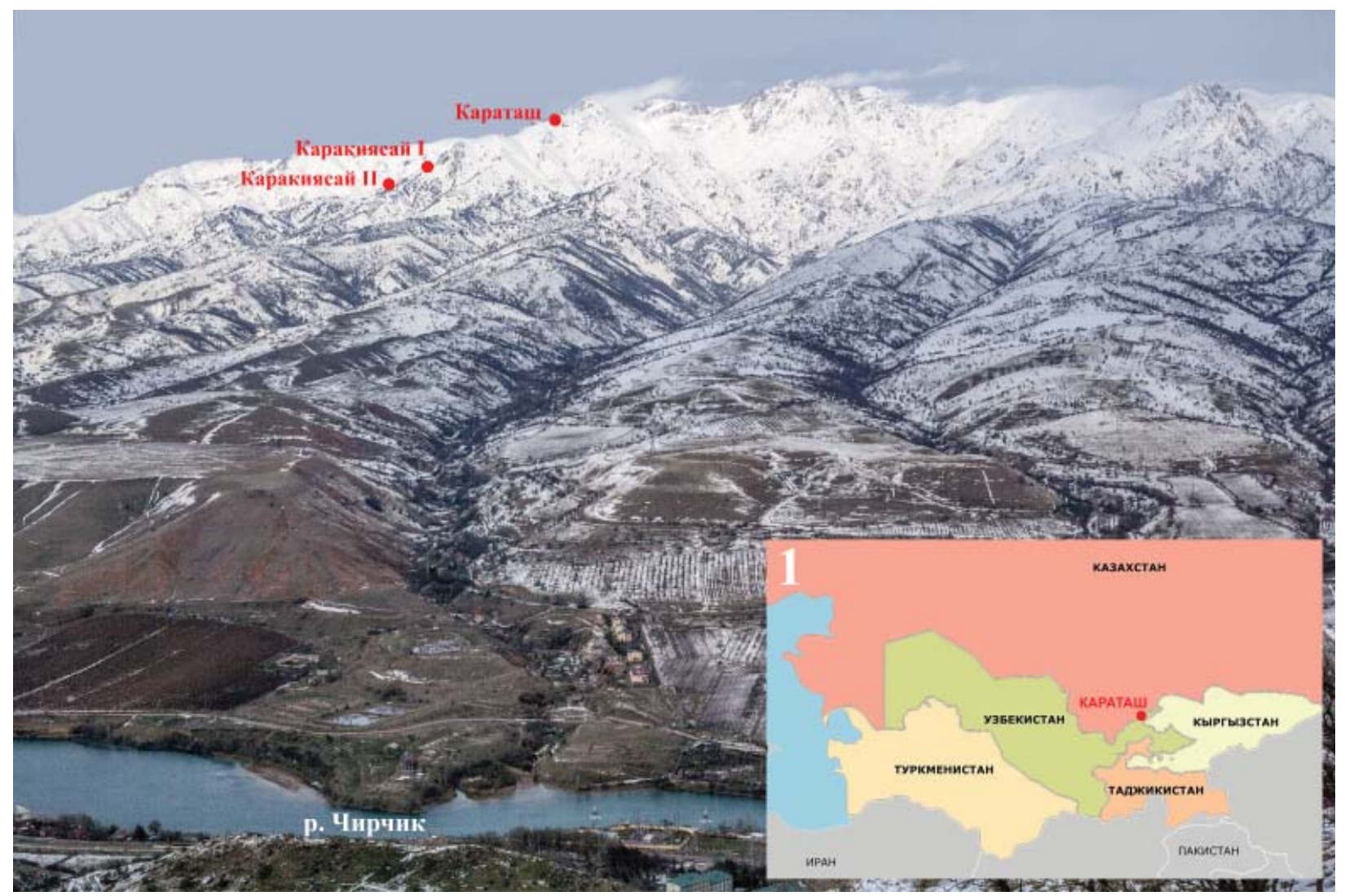

Рис. 1. Местоположение Караташа и основных скоплений петроглифов Каракиясая на хребте Каржантау: 1 - географическое положение камня с петроглифами.

Fig 1. Location of Karatash and the main clusters of Karakiyasay petroglyphs on the Karzhantau mountain ridge: 1 - geographical location of the stone with petroglyphs..

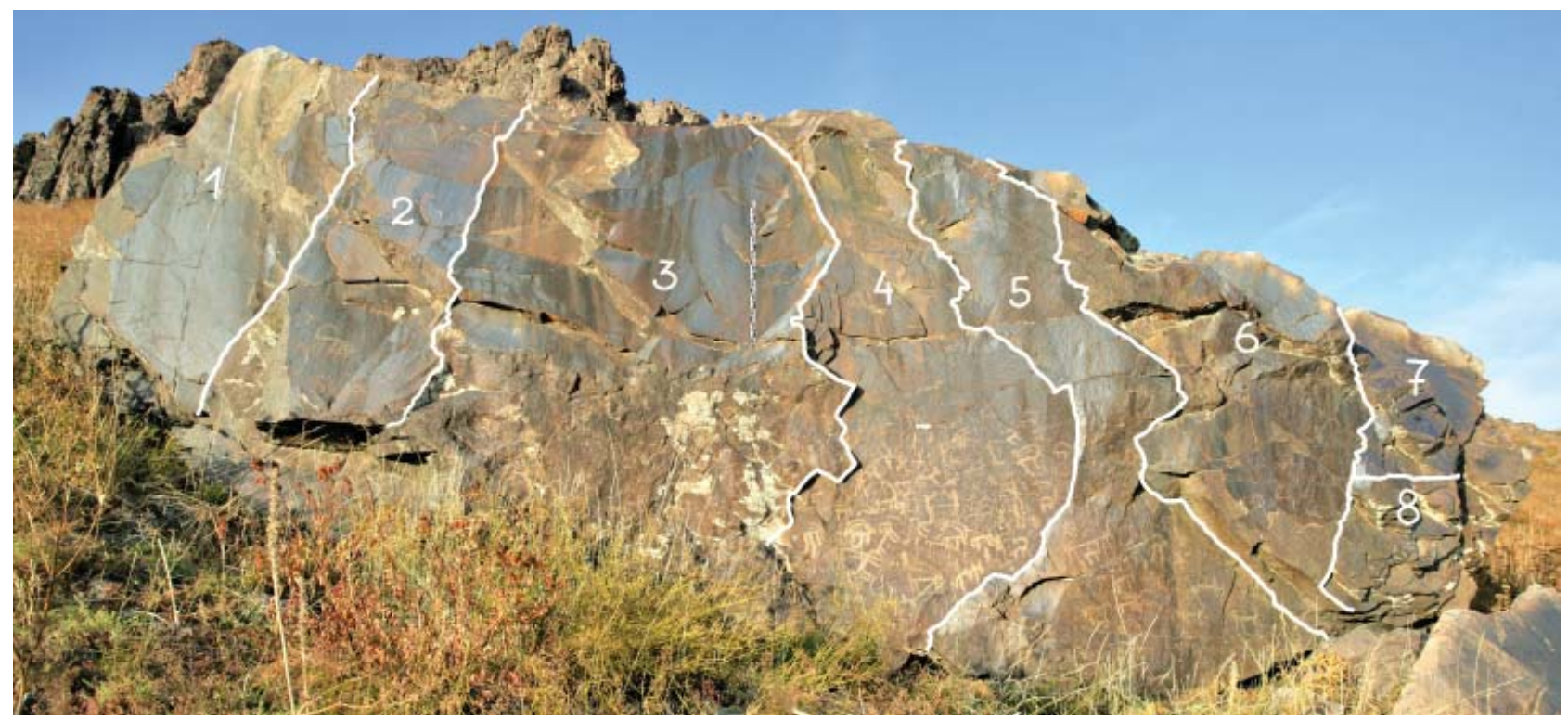

Рис. 2. Расположение 1-8 панелей на лицевой части камня.

Fig 2. Arrangement of panels 1-8 on the face of the stone. 


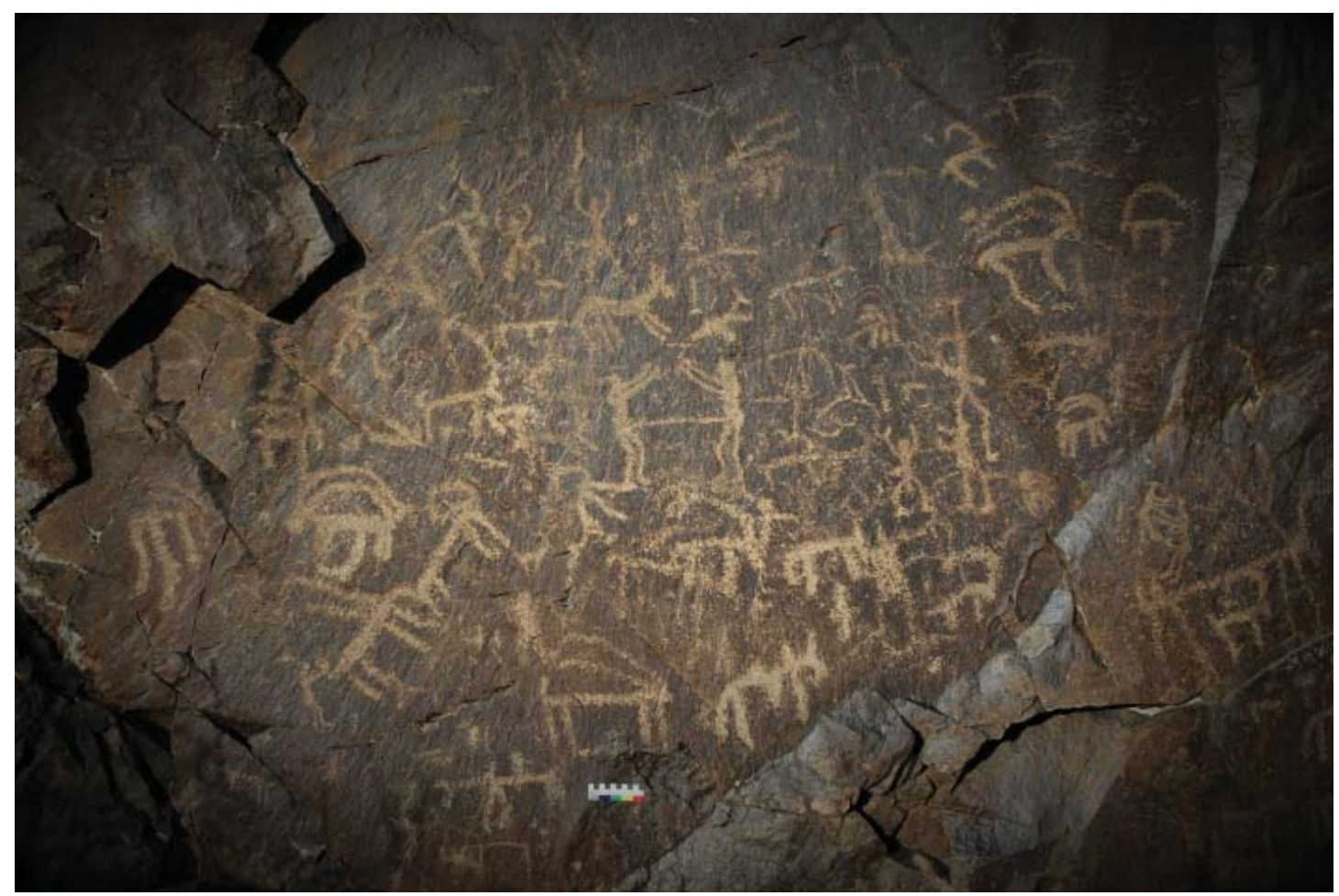

Рис. 3. Центральное панно Караташа (панель № 4).

Fig 3. Central painting of Karatash (panel No. 4).

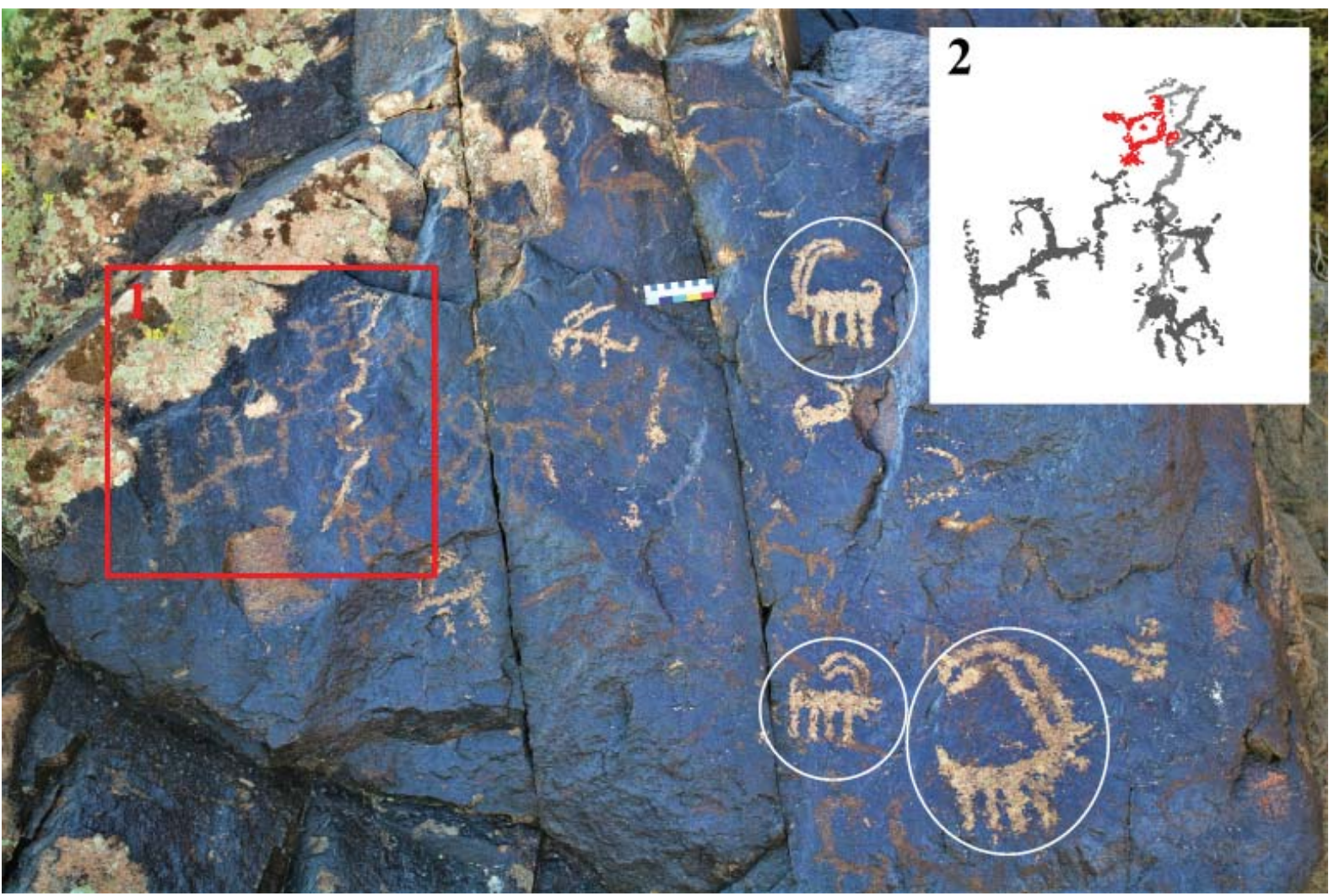

Рис. 4. Фрагмент панели № 15: 1 - участок с изображением знаков и волнистой линии; 2 - цифровая прорисовка участка № 1 (красным цветом прорисован знак, имеющий сходство с печатями из бактрийско-маргианского археологического комплекса); белым контуром выделены три случая подновления петроглифов.

Fig 4. Fragment of panel No. 15: 1 - area with signs and a wavy line; 2 - digital rendering of area No. 1 (a sign resembling the seals from the Bactrian-Margiana archaeological complex is outlined in red); three cases of petroglyph renovation are highlighted in white. 

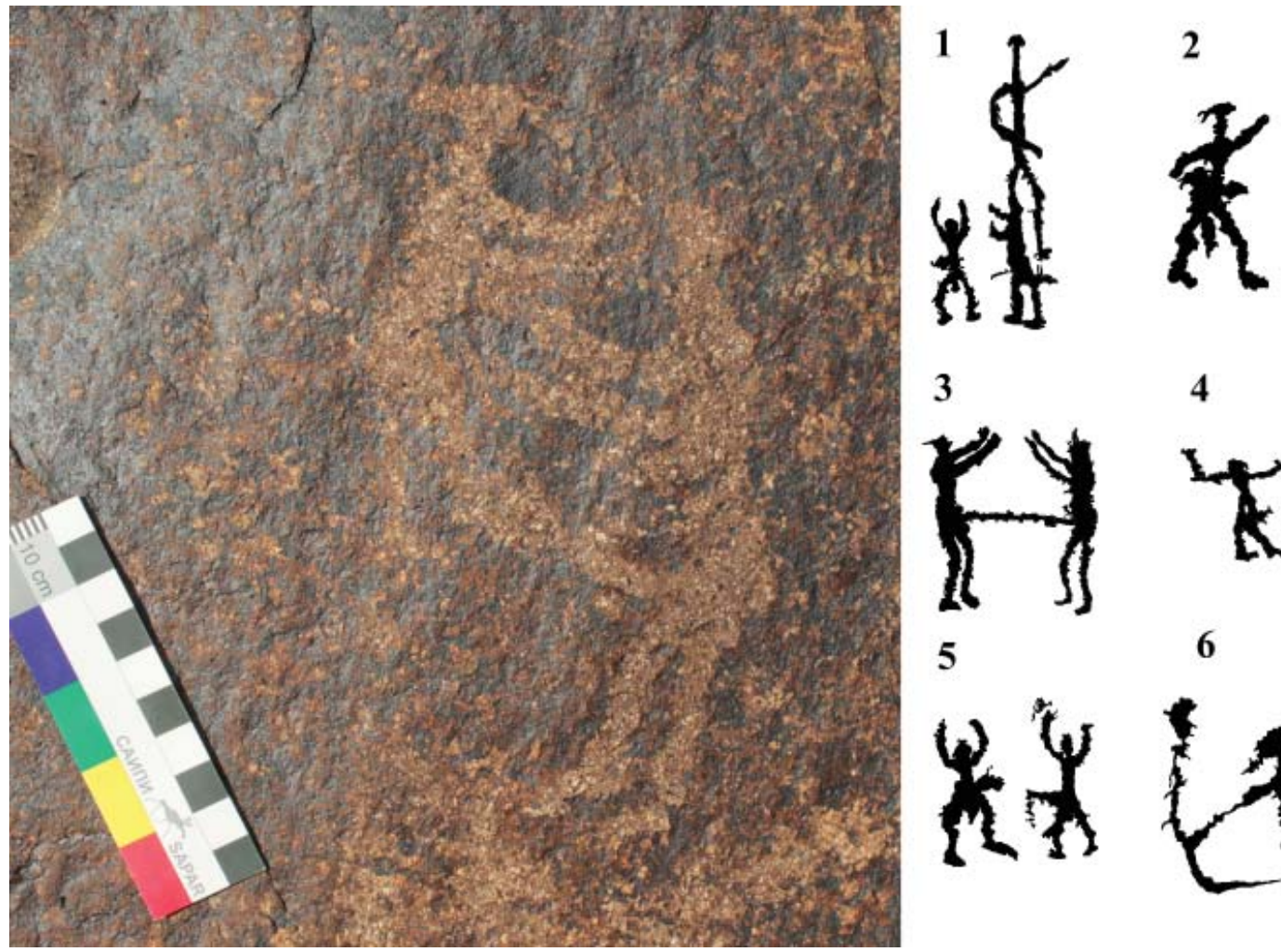

4

5

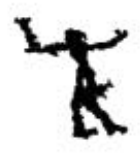

6
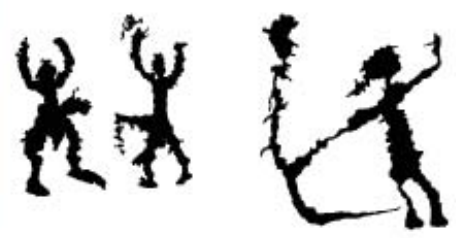

Рис. 5. Парные и одиночные антропоморфные образы Караташа.

Fig 5. Double and single anthropomorphic images of Karatash.

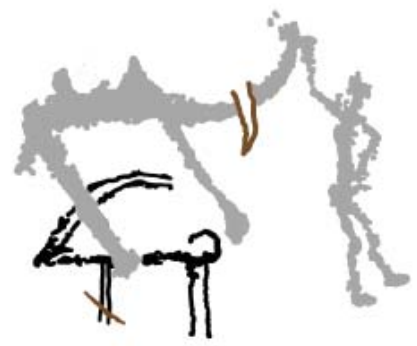

1

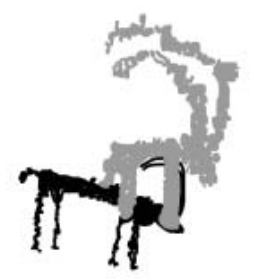

3

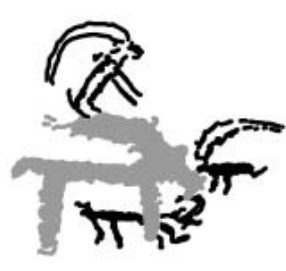

2

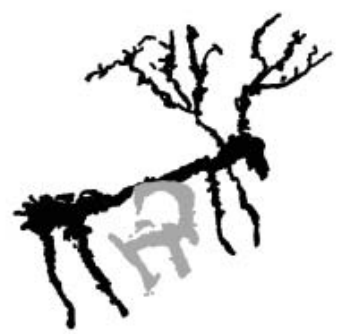

4
Рис. 6. Цифровая прорисовка палимпсестов Караташа: 1 - панель № 1; 2 - панель № 2; 3 - панель № 4; 4 - панель № 5.

Fig 6. Digital rendering of Karatash palimpsests: 1 - panel No. $1 ; 2$ - panel No. 2; 3 - panel No. 4; 4 panel No. 5. 


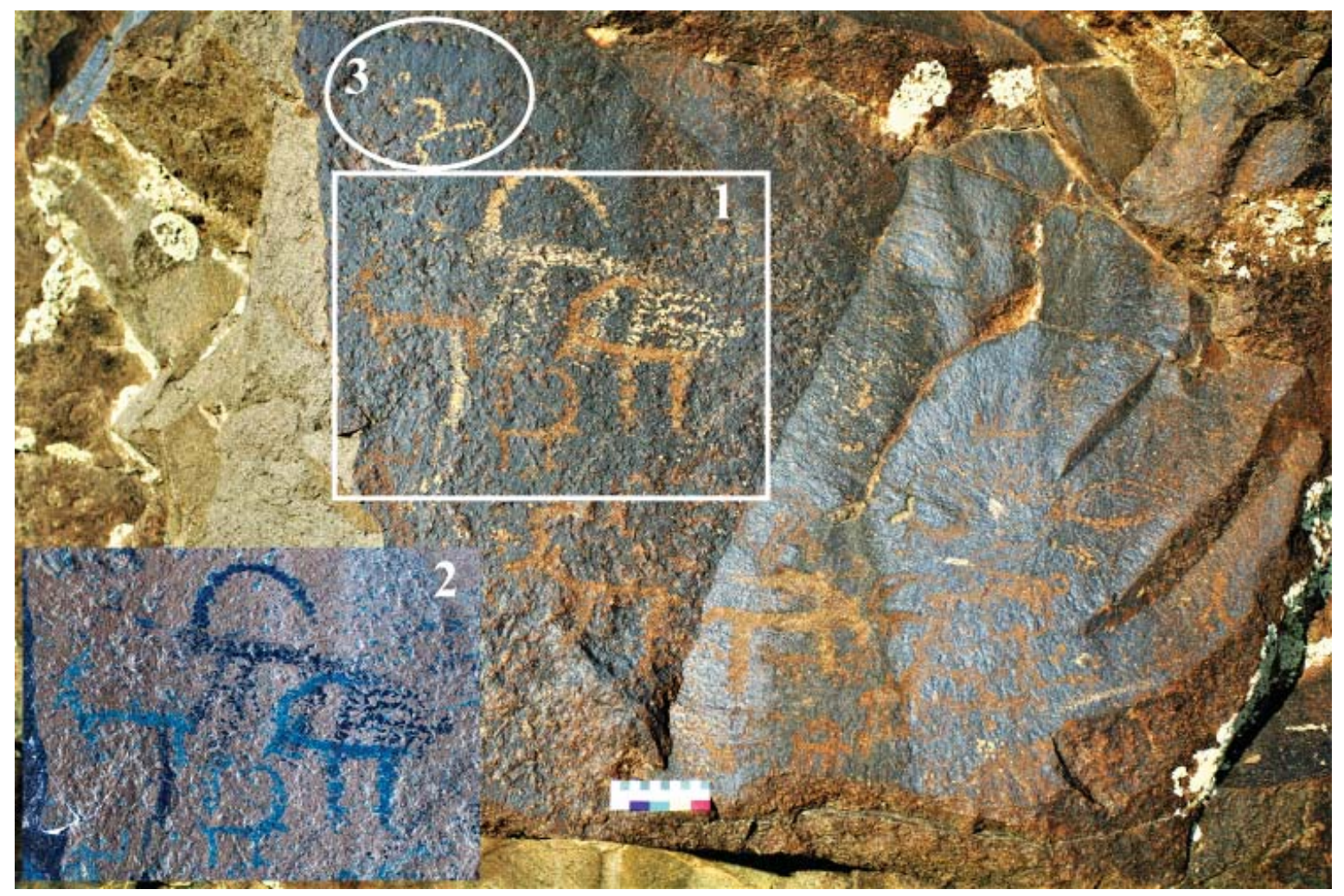

Рис. 7. Панно № 2: 1 - участок с палимпсестом; 2 - участок № 1, обработанный в цветовом пространстве Lab (Adobe Photoshop); 3 - тамгообразный знак.

Fig 7. Panel No. 2: 1 - palimpsest area; 2 - area No. 1 processed in the Lab (Adobe Photoshop) color space; 3 - tamga-shaped sign.

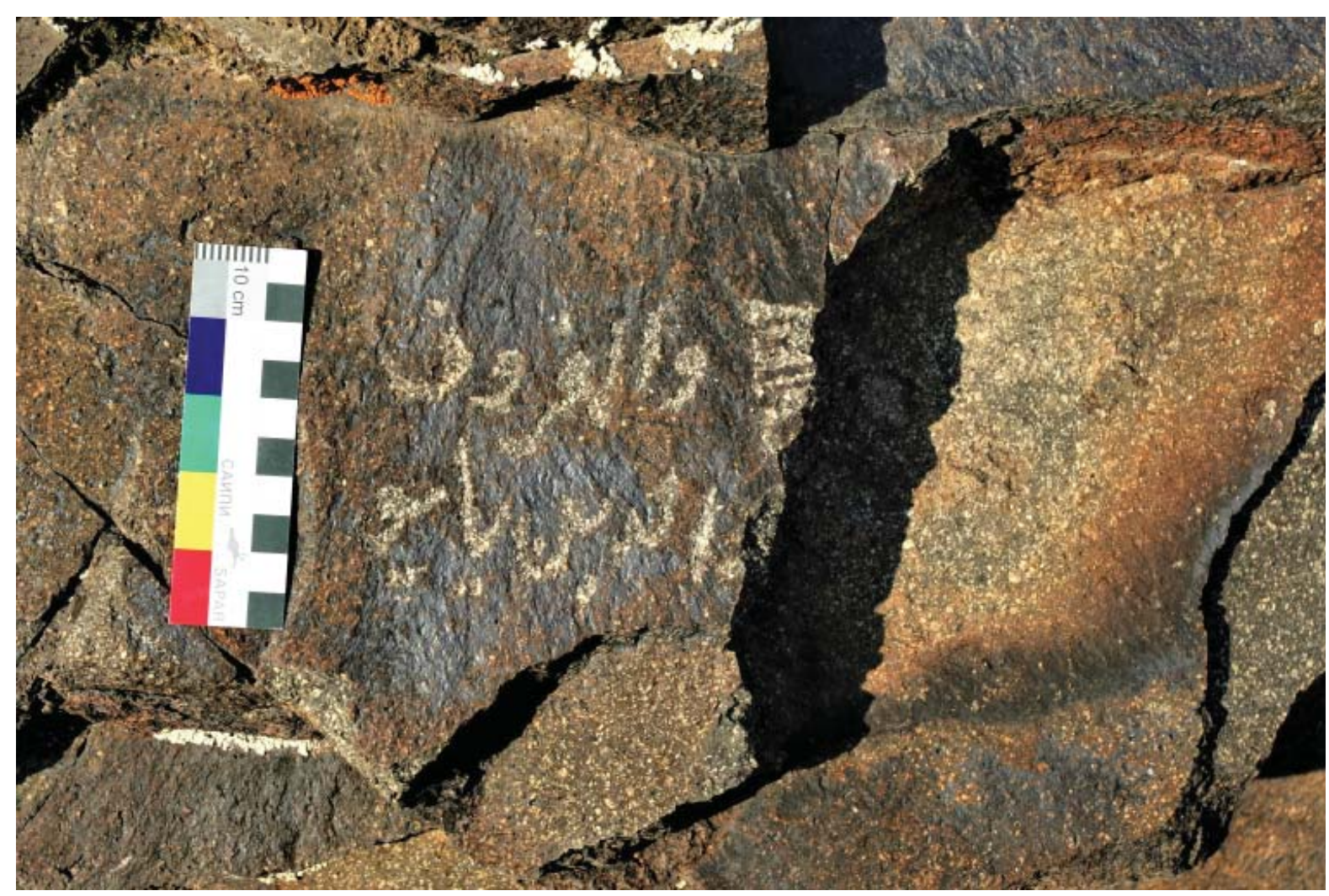

Рис. 8. Панель № 8 с надписью на арабской графике.

Fig 8. Panel No. 8 with an inscription in Arabic graphics. 


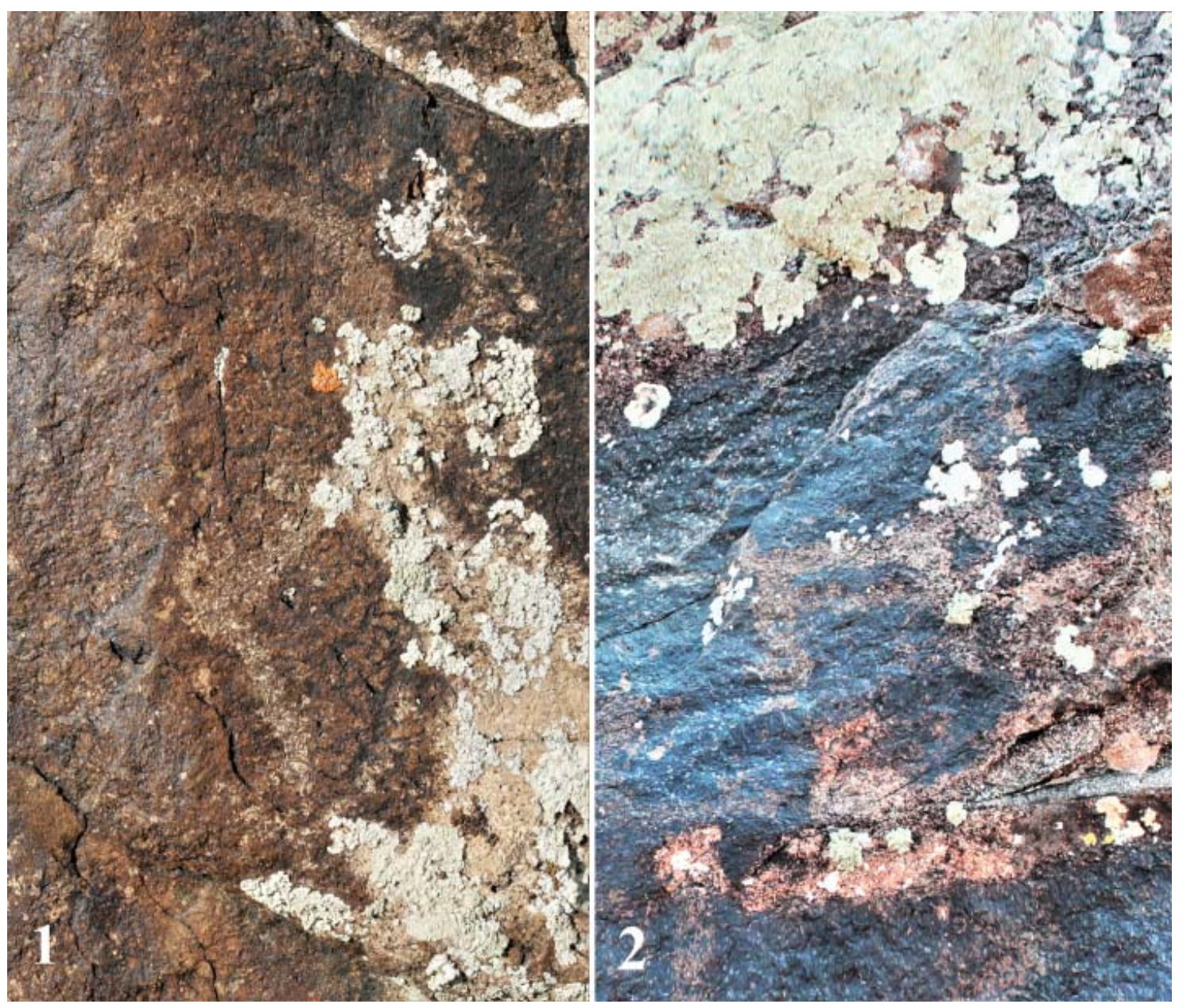

Рис. 9. Состояние сохранности петроглифов: 1 - панель № 3; 2 - панель № 11. Fig 9. Preservation state of the petroglyphs: 1 - panel No. $3 ; 2-$ panel No. 11. 